Tér és Társadalom 23. évf. 2009/3. 211-212. p.

\title{
KÖNYVJELZÖ
}

\section{VERES LAJOS: TÉRSÉGI LOGISZTIKA}

\author{
(Dunaújvárosi Föiskola Kiadói Hivatala, Dunaújváros, \\ 2008. 219 o.)
}

\section{KOMAREK LEVENTE}

Veres Lajos, aki a hazai regionális fejlesztések és kutatások egyik jeles képviselöje, több nagysikerü könyve után egy régen várt modern szemléletü, hiánypótló tankönyv megírására vállalkozott. Nem egyszerủ feladat a térségi logisztikáról tankönyvet írni, mert a különböző szemléletekkel megközelített témában nagyon könnyủ elveszni.

Könyve bevezetöjében a Szerző kiemeli, hogy a Dunaújvárosi Főiskola Gazdálkodás és Menedzsment szak keretében a Regionális gazdaságtan szakirányt választó hallgatók programjában szereplo „Térségi logisztika” c. tárgy inspirálta alapvetően a jól áttekinthetö, szakmai alapokon nyugvó tankönyv megírására. A Szerzö miközben bemutatja a logisztika már szélesebb körben elterjedt és alkalmazott, illetve oktatott ismereteit, arra törekszik, hogy felvonultassa és bemutassa a közgazdaságtudomány és azon belül is a regionális tudomány, regionális gazdaságtan eredményeit, amelyek közvetlenül kapcsolódnak a logisztika alkalmazásához.

A tankönyv első fejezete áttekinti a logisztika fogalmának hazai és nemzetközi sokszínüségét, a logisztika föbb feladatait, a többszörösen bővített logisztikai ellátási lánc (Supply Chain) és körfolyamat logikai sémáját, illetve a logisztika térhódítását. Veres Lajos szerint „a logisztika olyan stratégiai eröforrás, amely napjaink globalizálódó és élesedő piaci versenyében meghatározó lehet a vállalatok versenyképessége szempontjából" (13. o.).

A második nagy fejezet „A tér, az idő és a távolság” kérdéseit vizsgálja logisztikai szemszögből. Nagy hangsúlyt helyez a Szerző a termelöerők fejlődésének területi aspektusaira, az infrastruktúrára, mint a térbeli gazdasági rendszer fö elemére. Külön kitér a különbözö térfelosztásokra, amelyeket számos példán keresztül ismertet. Nem hagyja figyelmen kívül a telephelyválasztás föbb tényezőit, illetve a különböző telephelyelméleteket sem. Ebben a fejezetben kitüntetett szerepet szán a szállításnak, a közlekedési hálózatoknak, a gyors elérhetőségnek, megközelíthetőségnek, az árufuvarozási rendszereknek és az árueljuttatási megoldásoknak.

A harmadik fejezet a regionális tudomány és a logisztika kapcsolatát tárja az érdeklödő olvasó elé. A Szerző szerint megállapítható, hogy a két tudományterület számos ponton kapcsolódik és kölcsönösen hat egymásra. Ilyen kapcsolódási pontok a regionális tudomány kutatási területei, a regionális gazdaságtan vizsgálati témakörei, a regionális növekedés és fejlödés összetevőinek vizsgálata (a gazdasági folyamatok térbeli koncentrációjának kérdése, az endogén fejlödés szükségszerüsége és az inno- 
váció térbeli áramlása), a fenntartható fejlődés térbeli folyamatának értelmezése és a településközi kapcsolatok elemzése, a telephelyválasztás összefüggései.

A negyedik fejezet a térségi és gazdasági koncentrációkat elemzi. „A térségi, területi gazdasági koncentrációkban a kapacitás, a tőke, a munkaerő, a képesség, a tudás halmozódik, hozzáadódik, más szóval agglomerálódik." - írja a Szerző (78. o.) A fejezet első része a térségek fogalmi meghatározását (agglomeráció, agglomerálódás, agglomerálódó térség, település-együttes) mutatja be, míg a fejezet második része a gazdasági koncentrációkkal, a klaszter fogalmával, a hazai és a külföldi klaszterek bemutatásával foglalkozik.

Az ötödik fejezet a városfejlődés föbb vonásaival, a modern urbanizáció szakaszainak jellemzöivel, a városfejlesztési politika irányelveivel, illetve a városi logisztika sikertényezőivel ismerteti meg az olvasót. Külön kitér a városi elérhetőség és mobilitás fontosságára.

A hatodik fejezet a regionális logisztikai rendszerek kialakításának lehetséges vonásait vizsgálja. Ebben a fejezetben külön egységekben foglalkozik a közszolgáltatások, a hulladékgazdálkodás és az inverz logisztika jelentőségével. A közszolgáltatások alatt fogalmilag olyan feladatok ellátásának biztosítását érti, amelyek az adott feltételek között valamilyen mértékig közösségi szervezést igényelnek, és társadalmi közös szükségletek kielégítését szolgálják. A hulladékgazdálkodás témakörén belül a regionális hulladékkezelés hatásmechanizmusainak elvi alapjait foglalja össze. Az inverz logisztikai tevékenység alatt lényegében nem a hagyományos „ellátási lánc”-ot, hanem az úgynevezett „,begyüjtési lánc”-ot érti, amelyben sok helyről öszszegyüjtik a selejt árut, visszárut és a hulladékokat, majd a lerakóhelyre, vagy gyüjtőhelyre szállítják és a feldolgozókhoz juttatják el.

A hetedik fejezet a közlekedési rendszerek regionális kérdéseit taglalja, úgymint a regionális vasutak, a regionális repülötér-fejlesztések jelentőségét, illetve a közúti közlekedés regionális szerepét, a közúthálózat-fejlesztés logikai rendszerét.

A nyolcadik fejezet az intermodális logisztikai fejlesztési koncepciókkal, stratégiákkal, azok hazai és külföldi tendenciáival, fejlesztési irányaival foglalkozik. Az intermodális logisztika szakstratégia átfogó célja egy olyan logisztikai rendszer kialakítása, amely az ország kedvező geopolitikai helyzetének környezetkímélő kihasználásával a Kelet- és Dél-Európába irányuló elosztó-gyủjtỏ központi funkciók ellátására képes.

$\mathrm{Az}$ utolsó fejezet a logisztika és a globalizáció kapcsolatát vizsgálja. Külön kiemeli a globális-lokális paradoxon föbb jellemzőit, illetve külön kitér a virtuális vállalat logisztikai modelljére is.

Összefoglalásként elmondható, hogy a tankönyv stílusa élvezetes, lényegre törő, nyelvezete érthetö. A tankönyv szövegének megértését a jól szerkesztett, informatív ábrák és táblázatok segítik. Egy könyvismertetés azonban nehezen képzelhetö el kritikai észrevételek nélkül. Sajnos a tankönyv szövegközi hivatkozásaiból, elenyésző számban ugyan, de néhány kimaradt az irodalomjegyzékből.

A korszerü, sok új összefüggésre rámutató, tudományos igénnyel megírt hézagpótló munkát a térségi logisztika, a területi kutatásokkal foglalkozó szakemberek, a téma iránt érdeklődők és elkötelezettek nagy haszonnal forgathatják. 